\title{
PENGARUH KUALITAS LAYANAN TERHADAP KEPUASAN PELANGGAN PADA WARUNG KOPI CELEBEST DI KOTA PALU
}

Faigah A Badjamal', Maulid Sakaria ${ }^{2}$

(Dosen Fakultas Ekonomi Universitas Alkhairaat)

\begin{abstract}
ABSTRAK
Pengaruh kualitas layanan terhadap kepuasan pelanggan pada warung kopi celebest di kota Palu. Tujuan dari penelitian ini untuk mengetahui dan menganalisis pengaruh secara simultan kualitas layanan terhadap kepuasan pelanggan pada warung kopi celebest di Kota Palu. Adapun hasil penelitian yang didapatkan di lapangan bahwa hasil perhitungan regresi dapat diketahui bahwa koefisien determinasi (adjusted R2) yang diperoleh sebesar 0,401. Hal ini berarti 40,1\% kepuasan pelanggan dipengaruhi oleh bukti fisik, andalan, daya tangkap, jaminan dan kepedulian, sedangkan sisanya yaitu 59,9\% kepuasan konsumen dipengaruhi oleh variable-variabel lainnya yang tidak diteliti Dalam penelitian ini. kualitas layanan secara simultan berpengaruh signifikan terhadap kepuasan pelanggan pada warung kopi Celebes di kota Palu. Tangible Bukti fisik secara parsial berpengaruh signifikan terhadap kepuasan pelanggan pada warung kopi Celebes di kota Palu. reliability keandalan secara parsial berpengaruh signifikan terhadap kepuasan pelanggan pada warung kopi Celebes di kota Palu, responsiveness, daya tangkap secara parsial berpengaruh signifikan terhadap kepuasan pelanggan pada warung kopi celebest di kota Palu. Assurance, jaminan secara parsial berpengaruh signifikan terhadap kepuasan pelanggan pada warung kopi Celebes di kota Palu. Emphaty, empati secara parsial berpengaruh signifikan terhadap kepuasan pelanggan pada warung kopi celebest di kota Palu

\section{Kata Kunci: Kualitas Layanan dan Kepuasan Konsumen}

\section{LATAR BELAKANG}

Di zaman sekarang ini, meminum kopi di warung kopi telah menjadi sebuah kebiasaan masyarakat di Indonesia. bukan sekedar minum kopi Semata, namun di warung kopi juga menjadi tujuan beberapa kalangan untuk melakukan kegiatan suatu tertentu seperti bertemu klien atau belajar kelompok Bagi kalangan mahasiswa.

Era sekarang ini persaingan usaha warung kopipun juga semakin ketat dikarenakan begitu banyak warung kopi yang tentunya memiliki keunggulan tersendiri dalam produknya. Selain memiliki keunggulan dalam hal rasa, desain kedai maupun keunikan dalam penyajian, warung kopi juga memiliki pangsa pasar tersendiri. dengan begitu banyaknya usaha dalam mendirikan warung kopi menjadikan pelanggan mempunyai kriteria tersendiri dalam melakukan pembelian. dalam memenuhi keinginan dan kebutuhan masyarakat pelaku bisnis harus mampu mengetahui terlebih dalam Apa yang dibutuhkan dan apa yang diinginkan oleh pelanggan, kemudian Bagaimana cara agar dapat memberi kepuasaan terhadap pelanggan.

Pemenuhan kebutuhan masyarakat yang selain menjadikan minuman kopi sebagai gaya hidup dan persaingan warung kopi yang saat ini cukup ketat, memacu pelaku bisnis untuk memberikan kualitas pelayanan yang baik bagi pelanggan kualitas pelayanan merupakan suatu bentuk penilaian konsumen terhadap tingkat layanan yang diterima (perceived service) dengan tingkat layanan yang diharapkan (expected service). (Umar A, 2019) Kualitas pelayanan mempunyai pengaruh terhadap kepuasaan pelanggan, di mana kualitas pelayanan yang baik lah yang akan membuat pelanggan mendapatkan kekuasaan dan akan besar kemungkinan mempengaruhi keputusan pembelian pelanggan untuk kembali membeli produknya. Pelanggan 
yang puas akan cenderung memberikan referensi yang baik bagi orang lain

Kepekaan terhadap setiap perubahan harus dimiliki oleh setiap pelaku bisnis dan menempatkan orientasi kepada kepuasan pelanggan sebagai tujuan utamanya (philip kotler, 2005). Pelaku bisnis harus bergerak cepat dalam menyiapkan strategi agar dapat menyenangkan hati dan dapat membangun rasa antusias bagi para pelanggan. penciptaan suasana yang nyaman, desain interior yang menarik sekaligus adanya fasilitas WA-FI maupun live music menjadi daya tarik tersendiri bagi pelanggan.

Kepuasan pelanggan didefinisikan sebagai " perasaan senang atau kecewa seseorang yang muncul setelah membandingkan antara kinerja (perceived performance) produk akan sesuai dengan harapan seseorang pembeli" kotler (2009).

Menurut (Labandingi Latoki, 2020) Peningkatan kualitas akan jasa yang ditawarkan semakin mendapatkan banyak perhatian bagi perusahaan. Hal ini disebabkan karena kualitas jasa dapat digunakan sebagai alat untuk mencapai keunggulan kompetitif. Dengan adanya peningkatan kualitas jasa yang baik maka dapat menimbulkan suatu loyalitas konsumen, dan berkemungkinan besar menarik konsumen baru.

Menurut (Azis, 2019) Konsumen yang telah loyal pada suatu produk jasa menandakan konsumen tersebut merasa terpuaskan kebutuhannya sehingga akan melakukan pembeli lebih dari sekali. Hal tersebut sangat menguntungkan perusahaan, karena melalui terbuas nya kebutuhan konsumen, konsumen tidak akan melirik perusahaan lain dan dalam proses loyalitas tersebut, kemungkinan besar terjadi promosi gratis dalam bentuk world of mouth yang dilakukan oleh konsumen loyal kepada konsumen lainnya.

Menurut (Marjun, 2019) Implementasi kualitas jasa yang dilakukan oleh suatu perusahaan yang bergerak di bidang jasa adalah dengan memberikan kualitas pelayanan (service) yang terbaik bagi pelanggan dengan tujuan untuk menciptakan kekuasan pelanggan. Kualitas yang diberikan oleh perusahaan, akan menimbulkan persepsi pelanggan terhadap kualitas yang diberikan kepadanya. Seringkali terdapat perbedaan antara harapan pelanggan dengan persepsi pelanggan terhadap kualitas yang diberikan oleh perusahaan. Untuk mengetahui apakah perusahaan telah memberikan kualitas jasa yang sesuai dengan harapan pelanggan, maka perlu dilakukan evaluasi dari pelanggannya.

Kopi merupakan salah satu jenis minuman global yang dicintai oleh sebagai besar umat manusia dan memang sudah menjadi bagian dari gaya hidup.

Untuk menemukan minuman pekat Minuman berwarna pekat tersebut tidaklah sulit, dari mulai warung pinggir jalan, cafe, sampai restoran mewah maupun hotel berbintang pasti menyediakan kopi dengan variasi jenis dan harga yang berbeda. Kepopuleran kopi juga membawa dampak terhadap perkembangan bisnis, karena kini semakin banyak warung kopi atau cafe yang menjamur.

Di indonesia, coffee shop biasa disebut warung kopi atau kedai kopi. Warung kopi mulai hadir di tengah-tengah kita, mulai dari pelosok desa, hingga di pusat perkotaan. Definisi warung kopi menurut wiktionary (2009) bisa diartikan sebuah cafe kecil atau restoran kecil yang biasanya menjual kopi dan terkadangminuman non-alkohol, makanan sederhana atau snacks, dengan fasilitas yang menunjang di tempat tersebut. Senada dengan wiktionary, pengertian coffee shop atau warung kopi sendiri dalam kamus besar bahasa indonesia karya poerwadarminta (dikutip oleh anik, 2009) adalah " sebuah tempat yang menjual kopi dan jenis minuman lain, serta makanan-makanan kecil dengan harga yang murah".

Masyarakat indonesia melon bukan pengunjung cafe yang benar fanatik. Prosentase masyarakat yang sering mengunjungi warung kopi sangat rendah. Sebagian besar masyarakat kita jarang atau bahkan belum pernah mengunjungi warung kopi. Sedangkan pengunjung warung kopi hanya sebagian masyarakat yang kadang-kadang menggunakan jasa warung kopi. Jadi, warung kopi di indonesia hanya dikunjungi oleh konsumen dengan waktu internal tertentu. Oleh karena itu, situasi sektor warung kopi dapat dikenali melalui 3 (tiga) karakteristik (Rio Budi Prasadja tan, 2009):

1. Jenis usaha warung kopi tertentu yang tergantung pada jenis pelanggan tertentu, misalnya warung kopi mewah yang dikunjungi secara rutin oleh kelompok konsumen (kecil) tertentu yang berpenghasilan tinggi, namun tidak dikunjungi kelompok masyarakat lain. 
2. Kebanyakan usaha warung kopi dikunjungi oleh pelanggan tetap dengan interval kunjungan yang jarang frekuensinya.

3. Sebagian besar masyarakat indonesia tidak mengenal "budaya" warung kopi sisanya hanya mengenali sedikit, sedikit tarik namun tidak mau mengonsumsi waktu dan uang untuk sector warung kopi. Kelompok konsumen ini yang paling sulit digarap oleh warung kopi.

Dewasa ini di kota palu semakin marak warung kopi baru yang berdiri dan tersebar di pelosok kota. Akan tetapi tidak semua warung kopi di palu banyak dikunjungi oleh konsumen, hanya warung kopi tertentu yang terlihat ramai pengunjung. Ada banyak hal yang mempengaruhi pembelian di sebuah warung kopi salah satunya adalah layanan.

Berkembangnya warung kopi yang salah satunya di warung kopi celebes yang tepatnya berada di jln. H. Hayun yang ingin memenuhi keinginan dan kebutuhan konsumennya. Warung kopi menyediakan bermacam-macam jenis menu makanan dan minuman. Ada beberapa pesaing yang dihadapi warung kopi celebes dalam menjalankan bisnisnya antara lain warung kopi aweng, warung kopi tannaris, warung kopi sikamali, tungku coffe, nagaya coffe, dan masih banyak lagi yang tersebar di kota palu. warung kopi celebes merupakan sebuah usaha dagang yang bergerak pada industri jasa, yang didirikan pada tanggal 15 mei 2015. Konsep yang diterapkan oleh perusahaan dalam memasarkan produknya adalah warung kopi yang menawarkan menu kopinya dengan jaringan WIFI selain sekaligus live musik. Selain itu, cafe ini juga menawarkan jenis makanan lain serta minuman yang dapat dipesan melalui daftar menu. Warung kopi celebes merupakan salah satu warung kopi yang menghadapi ketat nya persaingan bisnis cafe pada saat ini.

Berdasarkan uraian latar belakang di atas, penulisan tertarik untuk melakukan penelitian ilmiah dengan judul "pengaruh kualitas pelayanan terhadap kepuasan pelanggan pada warung kopi celebes di kota palu"

\section{METODE PENELITIAN Jenis penelitian}

Penelitian ini menggunakan data yang diperoleh menggunakan data yang diperoleh melalui responden di mana responden akan memberikan respon verbal dan atau respon tertulis sebagai tanggapan atas pertanyaan yang di berikan melalui kuisioner, sehingga penelitian ini dapat di golongkan sebagai jenis penelitian explanatory (explanatory research). Explanatory research menurut rosady ruslan (2004; 13-14) adalah penelitian untuk tujuan menguji hipotesis atau untuk mengetahui adanya hubungan sebab akibat terhadap Suatu objek penelitian. Hipotesis ini sendiri menggambarkan hubungan antara dua atau lebih variabel berasosiasi atau tidak dengan variabel lainnya.

\section{Lokasi, Waktu dan Objek Penelitian}

penelitian ini mengambil lokasi penelitian pada warung kopi celebes yang beralamat di jalan H. Hayun, Besusu, Palu Timur, Kota Palu, Sulawesi Tengah 94111.

Waktu penelitian Januari-Maret 2020. Objek penelitian yaitu kualitas layanan dan kepuasan pelanggan.

\section{Jenis dan Sumber Data}

Jenis satu yang digunakan dalam penelitian ini adalah data kuantitatif dan kualitatif.

Definisi operasional variabel

Definisi operasional variabel yang dimaksud dalam penelitian ini adalah untuk memberikan penjelasan berupa dimensi-dimensi yang ada hubungannya secara langsung dengan penelitian ini. Definisi operasional variabel yang digunakan dalam penelitian ini adalah sebagai berikut :

1. Variabel kepuasan pelanggan (Y) mencangkup perbedaan antara harapan dan kerja atau hasil yang diharapkan.

Indikatornya terdiri dari :

$\mathrm{Y} 1=$ fasilitas yang diberikan

$\mathrm{Y} 2$ = sesuai dengan harapan

$\mathrm{Y} 3=$ merekomendasikan pada orang lain.

2. Dimensi bukti fisik (X1) merupakan sebagai fasilitas yang dapat dilihat dan digunakan perusahaan dalam upaya memenuhi kepuasan pelanggan.

Indikatornya terdiri dari :

$\mathrm{X} 1.1$ = ruangan memiliki dekorasi yang menarik.

$\mathrm{X} 1.2$ = lokasi warung kopi celebes mudah untuk ditemukan.

$\mathrm{X} 1.3=$ toilet bersih.

X1.4 = warung kopi celebes memiliki tempat yang nyaman

$\mathrm{X} 1.5=$ tersedia wifi.

$\mathrm{X} 1.6=$ tersedia live music 
3. Dimensi kehandalan (X2) merupakan kemampuan memberikan pelayanan kepada pelanggan sesuai dengan yang diharapkan, seperti melaksanakan jasa sesuai dengan apa yang telah dijanjikan secara tepat waktu dan kemampuan untuk meminimumkan kesalahan.

Indikatornya terdiri dari :

$\mathrm{X} 2.1=$ kecepatan karyawan dalam menyajikan pesanan

X2.2 = kecepatan karyawan dalam melakukan pelayanan.

$\mathrm{X} 2.3$ = kemudahan dalam prosedur pelayanan (pesanan makanan/minuman).

4. Dimensi ketanggapan (X3) yaitu sebagai sikap tanggap, mau mendengarkan dan merespon pelanggan dalam upaya memuaskan pelanggan.

Indikatornya terdiri dari :

X3.1 = karyawan mampu mengatasi keluhan pelanggan.

X3.2 = komunikasi yang baik antar karyawan dengan pelanggan.

$\mathrm{X} 3.3=\mathrm{ke}$ tanggapan karyawan dalam melayani pesanan pelanggan

5. Dimensi jaminan (X4) merupakan kemampuan karyawan dalam menimbulkan kepercayaan dan keyakinan pelanggan melalui pengetahuan, kesopanan serta menghargai perasaan pelanggan.

Indikatornya terdiri dari :

X4.1 = menjaga kesegaran makanan dan minuman.

$\mathrm{X} 4.2=$ pengetahuan karyawan tentang produk-produk yang disajikan.

X4.3 = kesopanan karyawan kepada pelanggan

6. Dimensi empati (X5) merupakan kemampuan atau kesediaan karyawan memberikan perhatian yang bersifat pribadi, seperti bersikap ramah, memahami kebutuhan dan peduli kepada pelanggannya.

Indikatornya terdiri dari :

X5.1 = sikap ramah karyawan terhadap pelanggan.

X5.2 = kemampuan karyawan dalam memberikan perhatian.

X5.3 = memahami kebutuhan pelanggan dalam pemesanan makanan dan minuman.

\section{Pengujian Hipotesis}

Uji t ( pengujian hipotesis secara parsial)
Untuk menguji ke berarti and model regresi untuk masing-masing variabel secara parsial dapat diperoleh dengan menggunakan uji t. Berikut akan dijelaskan pengujian masing-masing variabel secara parsial.

1. Variabel bukti fisik (tangible)

Hasil pengujian diperoleh nilai ut untuk variabel tampilan fisik (tangible) menunjukkan nilai $\mathrm{t}=6,790$ dengan nilai signifikansi sebesar $0,000<0,05$. Dengan nilai signifikansi dibawah 0,05 tersebut menunjukkan bahwa bukti fisik (tangible) memiliki pengaruh yang signifikan terhadap kepuasan. Hal ini berarti hipotesis 1 diterima. Arah koefisien regresi positif berarti bahwa bukti fisik memiliki pengaruh positif yang signifikan terhadap kepuasan konsumen. Semakin baik bukti fisik yang ada dalam perusahaan akan semakin tinggi pula kepuasan konsumen, sebaliknya semakin tidak baik bukti fisik yang ada dalam perusahaan semakin rendah pula kepuasan konsumen.

2. Variabel kehandalan (reliability)

Hasil pengujian diperoleh nilai t untuk variabel kehandalan (reliability) menunjukkan nilai $\mathrm{t}=$ 3,959 dengan nilai signifikan si sebesar 0,000 $<0,05$.

Dengan nilai signifikan si dibawah 0,05 tersebut menunjukkan bahwa kehandalan (reliability) memiliki pengaruh yang signifikan terhadap kepuasan konsumen.

Hal ini berarti hipotesis 2 diterima. Arah koefisien regresi positif berarti bahwa kehandalan memiliki pengaruh positif yang signifikan terhadap kepuasan konsumen. Semakin tinggi ke handal and pelayanan yang diberikan akan semakin tinggi pula kepuasan konsumen, sebaliknya semakin rendah kendaraan pelayanan yang diberikan semakin rendah pula kepuasan konsumen.

3. Variabel daya tanggap (responsiveness)

Hasil pengujian diperoleh nilai t untuk variabel daya tangkap (responsiveness) menunjukkan nilai $\mathrm{t}=2,660$ dengan nilai signifikansi sebesar $0,009<0,05$. Dengan nilai signifikansi dibawah 0,05 tersebut menunjukkan bahwa daya tangkap (responsiveness) memiliki pengaruh yang signifikan terhadap kepuasan konsumen. Hal ini berarti hipotesis tiga diterima. Arah koefisien regresi positif berarti bahwa daya tangkap memiliki pengaruh positif yang signifikan terhadap kepuasan konsumen. Semakin tinggi daya tangkap yang ada dalam 
perusahaan akan semakin tinggi pula kepuasan konsumen, sebaliknya semakin rendah daya tangkap yang ada dalam perusahaan semakin rendah pula kekuasaan konsumen.

\section{PEMBAHASAN}

Secara umum penelitian ini menunjukkan hasil yang cukup memuaskan.

Hasil analisis deskriptif menunjukkan bahwa kualitas pelayanan yang diberikan oleh warung kopi celebes secara umum sudah baik. Hal ini dapat ditunjukkan dari banyaknya tanggapan kekuasaan yang tinggi dari responden terhadap kondisi dari masing-masing variabel penelitian. Dari hasil tersebut selanjutnya diperoleh bahwa variabel kualitas pelayanan dan kelima dimensinya memiliki pengaruh yang positif dan signifikan terhadap kepuasan konsumen. Hal ini dikarenakan bahwa dengan pemberian pelayanan yang berkualitas, maka hal tersebut akan menciptakan kepuasan dalam diri konsumen.

Hasil penelitian menunjukkan bahwa variabel tampilan fisik memiliki pengaruh yang positif dan signifikan terhadap kepuasan. Hasil ini memberikan bukti empiris bahwa bukti fisik dari penyedia jasa yang ditunjukkan dengan fasilitas, interior dan sumber daya manusia sebagai pemberi pelayanan akan menentukan kepuasan konsumen.

Hasil penelitian menunjukkan bahwa variabel ke andalan memiliki pengaruh yang positif dan signifikan terhadap kepuasan konsumen. Hasil ini memberikan bukti empiris bahwa kah andalan dari penyedia jasa pelayanan di yang ditunjukkan dengan kehendak lan dalam bentuk kecepatan pelayanan, kemampuan pegawai, dan kah andalan pegawai dalam melayani konsumen akan dipertimbangkan dalam membentuk kepuasan konsumen.

Hasil penelitian menunjukkan bahwa variabel daya tangkap memiliki pengaruh yang positif dan signifikan terhadap kepuasan konsumen. Hasil ini memberikan bukti empiris bahwa daya tangkap dari penyedia jasa pelayanan yang ditunjukkan dengan kesediaan staf dalam membantu, persediaan staf dalam memberikan informasi, respon yang cepat dari karyawan, dan penyelesaian masalah dengan cepat akan memberikan pengaruh dalam terbentuknya kepuasan konsumen.

Hasil penelitian menunjukkan bahwa variabel jaminan memiliki pengaruh yang positif dan signifikan terhadap kepuasan. Hasil ini memberikan bukti empiris bahwa jaminan dari penyedia jasa pelayanan akan memberikan pada kepuasan konsumen. Hal ini ditunjukkan dengan kemampuan karyawan dalam melayani konsumen, karyawan yang mempunyai pengetahuan luas dan jaminan keamanan yang diberikan akan memberikan kesan yang lebih baik kepada warung kopi celebes sehingga meningkatkan kepuasan konsumen.

Hasil penelitian menunjukkan bahwa variabel kepedulian memiliki pengaruh yang positif dan signifikan terhadap kepuasan konsumen. Hasil ini memberikan bukti empiris bahwa adanya perhatian dari penyedia jasa pelayanan dalam bentuk perhatian yang sama, adanya layanan untuk tamu yang membutuhkan bantuan, kemampuan komunikasi yang baik, kemampuan dalam memenuhi kebutuhan konsumen dan pemahaman setiap kondisi konsumen akan meningkat pandangan positif dari setiap terhadap warung kopi celebes. Hal ini selanjutnya akan memberikan kepuasan yang lebih tinggi.

\section{KESIMPULAN DAN SARAN \\ Kesimpulan}

1. Kualitas layanan secara simultan berpengaruh signifikan terhadap kepuasan pelanggan pada warung kopi celebes di kota palu.

2. Tangible (bukti fisik) secara parsial berpengaruh signifikan terhadap kepuasan pelanggan pada warung kopi celebes di kota palu

3. Realiability (kehandalan) secara parsial berpengaruh signifikan terhadap kepuasan pelanggan pada warung kopi celebes di kota palu

4. Responsiveness (daya tangkap) secara parsial berpengaruh signifikan terhadap kepuasan pelanggan pada warung kopi cilebut di kota palu

5. Assurance (jaminan) secara parsial berpengaruh signifikan terhadap kepuasan pelanggan pada warung kopi celebes di kota palu

6. Emphaty (empati) secara parsial berpengaruh signifikan terhadap kepuasan pelanggan pada warung kopi celebes di kota palu

\section{Saran}




\section{Jumal Ekonomi Trend Vol. 09 No. 01 Januari-Juni 2021 E-ISSN. 2722-6565}

Untuk penelitian yang akan datang disarankan untuk menambah variabel independen lainnya selain bukti fisik (tangible), kehandalan (reliability), taya tanggap (responsiveness), jaminan (assurance), dan kepedulian (emphaty) yang tentunya dapat mempengaruhi variabel depan dan kepuasan konsumen misalnya, efisiensi pelayanan dan efektivitas pelayanan seperti yang disarankan oleh peneliti sebelumnya, agar lebih melengkapi penelitian ini karena masih ada variabel variabel independen lain di luar penelitian ini yang mungkin bisa mempengaruhi kepuasan konsumen.

\section{DAFTAR PUSTAKA}

Anik

.2010 .

Definisi

Coffee

shop.www.wiktionary.com. Diakses 12 April 2014

Azis, A. (2019). PENGARUH FASILITAS, KEMAMPUAN DAN DISIPLIN KERJA TERHADAP KINERJA PEGAWAI KANTOR KECAMATAN TINOMBO KABUPATEN PARIGI MOUTONG. Jurnal Ekonomi Trend, $7(2)$, 30-41. https://doi.org/10.31970/trend.v7i2.178

Basu Swastha (1999) Asas-Asas Pemasaran Edisi Ketiga Peneliti Penerbit Liberty Yogyakarta

Freddy Rangkuti 2004 Riset Pemasaran Jakarta: PT Gramedia Pustaka Utama.

Kotler, Philip dan keller Kevin lane (2009). Manajemen Pemasaran. Jakarta: PT. Indeks

Manajemen Pemasaran, Edisi 13 Jilid 1 dan 2, Jakarta: PT indeks

Labandingi Latoki, A. A. dan. (2020). PENGARUH HARGA, PROMOSI, LAYANAN PURNA JUAL, TERHADAP KEPUTUSAN KONSUMEN MEMBELI MOTOR METIC PADA PT GIOVANI PALU. Jurnal Ekonomi Trend, 8(2), 17-24. https://doi.org/10.31970/trend.v8i2.194

Marjun, M. (2019). PENGARUH DI MENSI DIMENSI KUALITAS LAYANAN TERHADAP KEPUASAN PASIEN RAWAT INAP BPJS KESEHATAN CENTER RUMAH SAKIT UMUM DAERAH ANUTAPURA. Jurnal Ekonomi Trend, 7(1), 12-26. https://doi.org/10.31970/trend.v7i1.170 
Nasir M.2009. Metodologi Penelitian, PT.Ghalia Indonesia Jakarta

Rio Budi Prasadja Tan, Dipl. Tour, M.A (2009). Psikologi Pelayanan Jasa Hotel, Resto, dan Kafe. Esensi erlangga group: Jakarta

Rosady, Ruslan. 2004. Metode Penelitian Public Relations dan Komunikasi. Jakarta:Raja Grafindo Persada

Sugiyono 2008 Metode Penelitian Kuantitatif Kualitatif dan R \& D, Bandung alfabeta

Supranto J 2006 pengukuran tingkat kepuasan pelanggan untuk menaikkan kepuasan pelanggan pustaka pelajar Yogyakarta

Tjiptono Fandy dan Gregorius Chandra 2005 Service Quality And Satisfaction Yogyakarta

Umar A, M. (2019). STRATEGI PEMASARAN DALAM UPAYA PENINGKATKAN VOLUME PENJUALAN PERUSAHAAN COMFORTA PALU. Jurnal Ekonomi Trend, 7(1), 27-40. https://doi.org/10.31970/trend.v7i1.171

Women J C dan Minor (1998) Perilaku Konsumen Erlangga Jakarta 